\title{
Teacher Understanding on the Implementation of Curriculum 2013 in Using Learning Models in Vocational High School, Banda Aceh, Indonesia
}

\author{
Fadhilah Razali ${ }^{\mathrm{a}, \mathrm{b}}$ \\ ${ }^{a}$ College of Arts and Sciences, Universiti Utara Malaysia, Kedah, Darul Aman, Malaysia \\ ${ }^{b}$ Faculty of Teacher Training and Education, Syiah Kuala University, Darussalam, Banda Aceh, Indonesia

\begin{abstract}
This paper is triggered by the issue of curriculum 2013. As a curriculum change, creativity and independence of the teacher are the major issue in implementing curriculum 2013. Teachers should have high competence in carrying out professional duty. Thereby, curriculum 2013 is directed to improve the capacity of teacher in achieving the objective of teaching. However, to ensure curriculum 2013 can be implemented effectively, it is important to determine teacher understanding in using learning model. Therefore, the objective of this paper is to analyze the teachers' understanding on implementation of curriculum 2013 in using learning models. It is expected that curriculum 2013 will support objective of Vocational High School in Banda Aceh, Indonesia in yielding qualified graduates in order to anticipate competition in today's working environment.
\end{abstract}

Keywords: $\quad$ Teacher understanding, implementation of curriculum, learning models

\section{Introduction}

Curriculum is one of the most important keys of today's school attention. Specifically, curriculum is statement on the general and specific objective of education which its material is selected and constructed in a particular pattern for the purpose of learning and teaching (Oliva \& Gordon, 2013). A Curriculum was used to direct students that is presented in the form of prescribed documents. It was arranged according to regeneration stages to be practiced in the classroom. Thus, curriculum is the setting used as a guide to conducting learning activities. According to Miller and Seller (1985), implementation of curriculum is a process of behavioral change as an innovation. It takes place in several stages and every time that solves various obstacles in its development. This implies that curriculum in the dimension of activity is manifestation of the effort to create a written document to be the latest in a series of learning activities.

It should be noted that every stage implementation of curriculum should consider the fundamentals or foundation of the curriculum. According to Murray Print (1993), foundation affects the shape and mind of the curriculum implementer into three basics foundation: (1) the philosophical foundation that explains the concepts that can be used as a result of comprehensible knowledge; (2) sociological basis: a social and cultural condition that affects the form of curriculum, (3) psychological foundation that observes, elaborates, predicts and inspects human behavior. Thus, the implementation of curriculum should be based on curriculum content. Brady (1992) emphasized the contents of the curriculum: (1) it can be interpreted as a subject which includes some factual information, knowledge, expertise, concepts, attitudes, and values, (2) curriculum content is important in teaching and learning process which contains of the two core elements; a contents and methods in a constant interaction. Meanwhhile, Zais (1976) stated that curriculum content usually consists of three elements namely knowledge, process and value.

Meanwhile, the teacher is the key holder of curriculum that acts as the designer and the implementer of actual curriculum. However, in the future, teacher is faced with many challenges in the learning process. Arends (2008) mentioned that teacher in the 21 st century faces seven major challenges, namely (1) teaching and technology (2) teaching with new insights on ability (3) teaching and choice (4) teaching and 
accountability (5) teaching for active learning (6) teaching for the construction of meaning (7) teaching in multicultural society. With these challenges, then the teacher should be able to carry out an effective curriculum design and achievement in the implementation of the curriculum. Thus the teacher should have a broad understanding of the curriculum both in theory and practice. Sumantri (1988) stated that the purpose of the curriculum was not to turn off the teacher's work, but instead, the teacher was assumed as the person who demonstrated his adaptation in implementing the curriculum. Thereby, in implementing curriculum, the teacher plays an important role in the teaching and learning process. Even though perfectly a curriculum, it has no meaning as the curriculum is just a written concept.

Furthermore, the responsibilities of teachers as learning manager can create a conducive learning climate. It involves both social and psychological climate and social well being as the purpose of learning management is to create a pleasant learning environment for students so that the students do not feel depressed in the process of learning. It is demonstrated by the creation of a harmonious relationship between teachers and students, teachers with teachers or between teachers and school leaders, while relationships psychology is demonstrated by the mutual trust and mutual respect for all elements in school. Through this climate it allows students to grow optimally, open and democratic.

However, the ability of teachers in using learning model becomes a crucial barrier that prevent teachers in implementing curriculum effectively. Thus, the teacher's understanding in making learning model should be improved. As stated by Nurahimah \& Rafisah (2010) in their study that the successful implementation of the curriculum is determined by teachers. They are an important asset in the national mission of education to deliver learning process more effectively. Teachers should be directed towards the creation of a world-class human capital. When teachers do not perform a good job despite the good conditions of education, the implementation of the curriculum will not run satisfactory. Thus, the task of teachers not only teaching, yet they are also someone involved in the implementation of the curriculum. Teachers are required to have a broad understanding of an insight into the theory and practice such as: have an understanding of the use of learning models.

\section{Implementation of the curriculum 2013 in Indonesia}

A Curriculum is a very important means for the triumph of an education. Learning activities organized by teachers are the main part of formal education with the absolute requirement of the curriculum as a guide. Teacher will be guided by the curriculum when designing program in the learning process. Kelly (2004) mentioned that an effective and productive of practical learning design offers a wealth of knowledge or subjects.

However, curriculum will not be meaningful when it is not implemented in the form of learning as a plan or program. Without a clear curriculum as a reference, then learning will not take place in an effective method. Thus, learning activities by the teacher start with the component of learning listed in the curriculum. Siraj (2008) mentioned that the curriculum is all the experience by each individual learner in an educational program that aims to achieve broader goals and related objectives. It has been designed in the form of a framework theory and study or professional practice in the past and present.

Currently, the curriculum is designed with the characters. In Indonesia, the curriculum has been applied for several times since 1968, 1978, 1984, 1994 (curriculum based on competency) and also in 2004. Various analyzes show that Indonesia's current national education is faced with various problems. This is a crisis that needs to be controlled as quickly as possible, such as curriculum change and implementation. It shows that curriculum should be designed in order to further develop the potential of the students. Thus, the curriculum does not overload students.

Implementation of curriculum 2013 is a change of the old curriculum. In its implementation, this curriculum is created by teachers in each educational unit (school). Thus the curriculum can be more adapted to the situation in each area. Changes of the previous curriculum into the curriculum 2013 as a new curriculum, hopefully, a momentum for the improvement of the quality of education in Indonesia, which means improving the overall quality of Indonesian human resources. This is especially important when it is linked to Millennium Development Goals 2015. Changes of the curriculum are also multi-dimensional, in 
other words involving at least three- dimensional components of its implementation. Fullan (1993) says its components are as follows: (1) the use of revised or new or technological curriculum materials, (2) the use of new approaches, (3) transformers in accordance with the beliefs, for example, new or innovative.

Therefore, curriculum 2013 is built on the development of personality (humanistic curriculum), which is oriented towards the curriculum to life and the nature of work (reconstruction of social and technological). Thus, a curriculum is oriented to the nature of work, namely social reconstruction curriculum and technology. As stated by Nurhadi (2003), a curriculum should be able to follow the dynamics of society. The curriculum should address the needs of the general public in dealing with the problems of life. It should be noted that the curriculum is renewed in line with the reality of the education world in providing the students to be human beings who are ready to live in various circumstances. The curriculum must be responsive to the social, relevant and accommodative diversity of importance and technological advances.

In implementing the curriculum, the task of the teacher should at least have the following abilities and attitudes: (1) in implementing curriculum, teachers should know the boundaries of the material to be presented in teaching, both the extent of the material, the concept or the degree of difficulty as set out in the curriculum, (2) master the content of the taught materials. Teachers are not only required to complete the prescribed lesson material but must also master and deeply comprehend all the materials taught, (3) master the methods and assessment of learning, (4) responsibility for the task, (5) fifth, discipline in broad terms. Thus in the implementation of curriculum, the teacher's task is very hard (Rusman, 2009). Hence, the adoption of curriculum 2013 in the Indonesian education system is not only a curriculum change. Implementation of curriculum 2013 is also expected to achieve the learning objectives because with the adoption of the curriculum 2013 that there will be changes in the concepts, methodologies, and strategies of teachers in teaching.

\section{Teacher understanding in using learning media}

Teachers are the forefront of creating human resource qualities, as through a learning process of teachers dealing directly with students in the classroom. It is required teachers who have high dedication, eligibility, and competence in carrying out professional duty. Thus, teachers need help to improve their skill in facing new challenges as curriculum implementer (Nurahimah \& Rafisah, 2001). The curriculum is expected to be implemented effectively to improve the quality of learning. Teachers need to engage teaching as a profession, like what is taught, understand and master the basic competencies and other competencies that have to do with good, understanding students, using different methods of teaching, follow recent developments, the completion of the learning process, connect past experience with the competencies to be developed (Mulyasa, 2007).

For the future, teachers should be able to perform/design an effective curriculum to achieve goals and objective that have been set. Thus teachers are required to have a wide understanding and insight about the curriculum well both theoretically and practically. Sumantri (1988) stated that the purpose of the curriculum is not to disable the initiative and work of the teacher, but instead, the teacher is seen as the person who shows his creations and adaptations in implementing the curriculum. Nasution, (1995) confirmed that teachers are always the main figure to realize the curriculum in order to change students' behavior according to what is expected. Teacher's understanding of curriculum change can create obstacles for teachers in their implementation.

Rusman (2009) mentioned that the ability to be possessed by teachers in the curriculum implementation includes: understanding of the goals to be achieved, the ability to develop curriculum goals more specifically, the ability to achieve specific goals into learning goals. According to Swetz \& Subahan (1981), these obstacles indicate a weakness in terms of teacher proficiency and teacher knowledge. There are some barriers can be found in curriculum change such as issues in making lesson plans, creating modules, using the media and learning models. 
Siti Hawa (1986) claimed that a change to be successful if the teacher is willing to accept new ideas and be able to be brought into the practice or class. This is not an easy job to do if the teacher does not have a strong understanding and the school does not facilitate it. Subahan (1999) stated teachers are facing problems to understand how the change should be implemented. However, a teacher will not reject for implementing if the change is not complicated. Dembo \& Gibson (1985) in their findings concluded that the commitment of teachers to implementing innovation in the classroom is much influenced by their perceptions of innovation itself. These perceptions influence their attitudes and behaviors in the process of teaching and learning. Some studies indicate early implementation of curriculum change is not effective. Sukumaran (1998) found that teachers are difficult to implement changes in the form of evidence-based teaching styles rather than studies indicate a lack of empowerment to implement change.

In learning activities, a suitable and efficient learning can be done by the teacher to achieve the purpose of learning. Learning models can be used as patterns, the depiction of the activities of teachers and students in creating a learning environment called learning patterns. Activities performed by teachers and students can be explained in learning patterns that is a learning activity designed or constructed with specific learning patterns (Joice \& Well, 1980). Thus, design or pattern which is used as a guide to be regarded as a model of learning. The learning model is referring to the learning approach used, for example in the management class, the stages of learning activities, and learning goals (Arends, 1997). The teacher may use instructional models in the learning process. The learning model is a design or pattern that may be used by teachers in the classroom. The Learning model is a general pattern of learning behavior in achieving the expected learning objectives to guide lesson (Trianto, 2011). Models of learning refer to learning approaches which will including teaching objectives, stages of learning activities, learning, and management class. Using a learning model can help the teacher to have satisfaction in teaching. Teacher understanding in using learning models indicate teachers have a certain style of teaching. The results of the study showed that teachers have higher job satisfaction does not feel overly stressed his deep using a particular teaching style. Precisely, the teacher will have a commitment to the college profesion (Noriah, 2003).

Media is a tool to stimulate the students to the learning process. All the learning media that include tools and materials are to deliver content and learning materials. For the purpose of teaching or conveying content it can utilize the media as a technology comprising books, tape recorders, cassettes, video cameras, video recorders, movies, pictures, photos, television and computers, so the role of the media must be fully utilized (Siti Hajar, Sukri, \& Mohd Razha, 2011). Teachers should have an understanding of good learning media provided by the school. They can use low-cost and effective tools at least as simple and unpretentious but as a necessity in achieving the expected teaching objectives.

Hence, in the process of learning, teachers need to understand the use of media. For that reason, teachers should have enough understanding of the learning medium (Hamalik, 1994). Azhar (2010) stated that sending information between sources and recipients was said to be media. Media is an intermediary form to convey or disseminate ideas made by humans so that ideas or opinions can reach the recipient (Latuheru, 1993). The findings of the study of Akinyemi (1986) illustrated the existence of anxiety and fear of curriculum changes involving the use of technology termed as technophobia. He found that his technophobia among school teachers in Nigeria was due to three factors: (a) fear of technology media, (b) fear of electronic equipment, and (c) fear of the role of teachers being taken by the media.

However, the understanding of the teachers in making learning models should be improved to achieves the goals of learning. Trianto (2011) mentioned that learning tools or models include: Learning Plan, syllabus, modules (student books), learning media, learning models, student activity sheets and learning outcomes. According to Muslich (2009). Learning Plan should have a high applicable understanding due to the understanding of teachers in making modules can consolidate to the condition better learning well (Diknas, 2008). Similarly, in the study of curriculum innovation in Malaysia, Azizah (1987) stated that teachers experience complexity in carrying an teaching approach centered teaching approach is because they do not receive sufficient 
training. Thus, teachers' knowledge of understanding makes Learning Model, modules, using media and learning models need to be adequately trained.

Thus, Hamalik (1993) stated that teachers should be able to develop the skills to create the learning media that will be used when the media is not ready. Teachers also should be able to use the tools properly, so teachers should have enough understanding of the learning media. Without the help of the media, educational materials are difficult to understand by students (Jamarah, 2010). Gagne and Briggs (1975) stated that the learning media was used to deliver the contents of the educational materials. Media is a physical vehicle. It contains instructional materials that can stimulate students to learn in the student environment. The use of instructional media as an auxiliary tool can enhance student understanding and facilitate educators to communicate knowledge, can attract students to follow a better learning process (Davina, 2003)

\section{Implementation of Curriculum 2013 in Vocational High School, Banda Aceh, Indonesia}

Vocational High School is one program of the schools in Aceh, Indonesia. As part of the national education system, Vocational High School is an education that emphasizes the development of students' ability to work in certain industries. Ability to adapt to the work environment, to look at job opportunities and to develop themselves. In other words, that Vocational High School plays a role in preparing students to be ready to work in the industrial world independently or to fill their jobs.

Therefore, the implementation of the curriculum in Vocational High School should be implemented intimately because Vocational High School graduates are expected to be human beings who can improve the quality of life, develop themselves and have the expertise and courage to open up job opportunities to increase income both to create jobs for themselves and others, this can change the status of the nation from dependence to a nation of income. Indeed, implementation of curriculum 2013 is very relevant to support the objective of Vocational High School in Banda Aceh. Curriculum 2013 is an increase in the competence-oriented attitude, skills, and knowledge. According to the Department of Education (2013), the distinction of the old and new curriculum are: the curriculum in 2006, has not been fully competency-based, competency not describe a holistic manner, the domain of attitudes, knowledge, and attitudes. Some competencies are required as character education has not been accommodated in the curriculum, and the curriculum in 2006 have not been sensitive towards social change. While the Curriculum 2013 requires the addition of school hours. Changes in the learning process of ' students told ' to ' learner to find out '.

In the implementation of the curriculum in 2013 at Vocational High School, Banda Aceh, teachers are expected to have an understanding in using the leaning models. Thus, teachers can apply classroom learning process according to the material being taught, on the other hand, the use of learning models. It can be understood the ability of teachers to implement the curriculum 2013 as designed. Implementation of curriculum 2013 will manifest in the learning process so as to see the impression of its implementation in the field is to look at the implementation of the process of learning and teaching or learning activity which is essentially how the message and content of the curriculum can be delivered to students. it is aligned with the opinion of Hasan (1984) that stated implementation of the curriculum is an attempt to realize the curriculum is written into reality.

\section{Conclusion and Suggestion}

Curriculum 2013 has been implemented at Vocational High School, Banda Aceh, Indonesia. However, in its implementation can be found several weaknesses such: teachers have no understanding expected to implement new curriculum, pattern of curriculum implementation is disrupted with teacher and school problem because some teachers cannot contribute ideas creative to implement the curriculum, the completeness of the implementation of the new curriculum is not available so that the lack of facilities and demands the availability of complete facilities and infrastructure. Meanwhile, the situation in the field showed that a lack of learning media and laboratory equipment that can not be used maximally in the learning process. In compiling and practicing curriculum 2013. Teachers still have difficulty in understanding it thoroughly due to the socialization on the 
implementation of curriculum 2013 has not one yet. The objective to be achieved by strengthening curriculum 2013 will face problems if the stage of socialization cannot be achieved comprehensively.

The goal of learning management is the creation of a learning environment that is fun for the students so that in the learning process students do not feel forced let alone depressed. Therefore, the responsibility of teachers as learning managers can create a conducive learning climate, both social climate and good psychological and social climate is shown by the creation of good harmony relationships between teachers and students, teachers with teachers or between teachers and school leaders, while relationships psychology is shown by the existence of mutual trust and mutual respect for all elements of school. It is through this climate that allows learners to develop optimally, openly and democratically. Furthermore, every curriculum change is expected to have adequate training for teachers, so teacher can play an active role. In learning activities, all the concepts, principles, values, knowledge, methods, tools and skills of teachers in the form of deeds will realize the form of a real curriculum (actual curiculum). The ability of the teacher is examined in the classroom practice. The embodiment of the concepts, principles, and aspects of the curriculum depends on the ability of teacher as the curriculum implementer.

To improve teachers' readiness in the implementation of the curriculum 2013 in Vocational High School, Banda Aceh. There needs an improvement activity. Such activities can be conducted through discussions, simulations in the peer group as well as through workshops, training, and internal upgrades by presenting speaker.

\section{References}

1. Akinyemi, K. (1986). A Study of technophobia among primary school teachers in Nigeria. Programmed learning and educational technology, 5(1), 263-269

2. Arends, Richard. (2007). "learning to teach", Avenue of the Americans New York, NY 10020: McGraw-Hill Companies, Inc 1221.

3. Arends, R. (2008). Learning to teach. NewYork: McGraw-Hill Companies

4. Azizah Ab. Rahman, (1987) Curriculum innovation in Malaysia. The case of KBSR. Phd University London
5. Azhar Arsyad. (2010). Media pembelajaran. Jakarta: PT. Raja Grafindo Persada.

6. Brady. (1992). Curriculum development (Third Edition). Australia: Prentice Hall.

7. Dembo, M., \& Gibson, S. (1985). Teachers sense of efficacy: an important factor in scholl achievement. The elementary scholl journal, 86,173,184.

8. Departemen Pendidikan Nasional. (2008). Teknik menyusunan RPP. Jakarta: Direktorat Pembinaan Sekolah Menengah Kejuruan.

9. Fullan, M. G. (1991). The new meaning of education change, New York: Teacher College Press Published

10. Gagne, R. M. (Ed.). (1987). Instructional technology: foundations. Hillsdale: Lawrence Erlmaum Associates, Publishers

11. Hamalik Oemar. (1994). Media pendidikan (Cetakan Ketujuh). Bandung: Penerbit PT. Citra Aditya Bakti.

12. Jamarah. (2010). Strategi belajar mengajar. Jakarta: PT. Rineka Cipta.'

13. Joyce \& Weil. (1980). Model of teaching englewood cliffts. NJ: Prentice-Hall Inc.

14. Kelly, A.V. (2004). The curriculum theory and practice fifth edition.London. Sage Publications.

15. Latuheru, J D. (1993). Media pembelajaran dalam proses belajar - mengajar kini. Ujung Pandang: Penerbit IKIP Ujung Pandan

16. Miller, J. P., \& Siller, W. (1985). Curriculum: perspective and practices. NewYork: American Book Co.

17. Mulyasa Enco. (2007). Kurikulum tingkat satuan pendidikan sebuah panduan praktis. Bandung: Remaja Rosdakarya

18. Mulyasa Enco. (2008). Pelaksanaan kurikulum tingkat satuan pendidikan. Jakarta: PT. Bumi Aksara

19. Murray Print. (1993). Curriculum development and design. Australia: Allen \& Unwin.

20. Nasution, S. (1993). Pengembangan kurikulum. Bandung: PT. Citra Aditya Bakti.

21. Nurahimah Mohd Yusoff \& Rafisah Osman. (2010). Hubungan kualiti penyeliaan pengajaran dan pembelajaran di bilik darjah dengan efikasi guru. Journal of Educators and Education. 25, 53-71. Asia fasifik

22. Nurahimah Mohd Yusoff \& Rafisah Osman. (2001). Penyeliaan Pengajaran. Pusat sumber pendidikan Negeri Kedah Darul Aman. Jurnal Wawasan. 15(2) Desember 2001. 
23. Noriah Mohd Ishak \& Nor Sakinah Mohammad. (2003). Kesan interaksi antara gaya pertautan, gaya pengajaran dan komitmen terhadap profesyen keguruan. Jurnal Pendidikan. 28. UKM Bangi Selangor. DE. Malaysia

24. Oliva, P. F., \& Gordon, W. R. (2013). Developing the curriculum. Boston, MA: Allyn and Bacon.

25. Rusman. (2009). Manajemen kurikulum. Jakarta: PT. Raja Grafindo Persada

26. Siraj, S. (2008). Kurikulum masa depan. Kuala Lumpur: Universiti Malaya.

27. Sumantri, M. (1998). Kurikulum dan pengajaran. Jakarta: Depdikbud. P2LPTK.

28. Siti Hajar Halili, Sukri Sulaiman \& Mohd Razha Abdul Rayid. (2011). Keberkesanan proses pembelajaran menggunakan tehnologi sidang vidio. Jurnal pendidikan Malaysia. 36 (I).

29. Subahan Mohd. Meerah, (1999) Dampak penyelidikan pembelajaran sain terhadap perubahan kurikulum. Universiti Kebangsaan Malaysia.

30. Swetz, F. \& Subahan. (1981). Dampak Penyelidikan pembelajaran sain terhadap perubahan kurikulum. Bangi: Universiti Kebangsaan Malaysia.

31. Trianto. (2011). Model pembelajaran terpadu. Jakarta: PT. Bumi Aksara.

32. Zais, R. S. (1976). Curriculum prinsiples and foundation. London: Heper and Row. 